Department of Food Hygiene,

Faculty of Veterinary Medicine,

Assiut University, Assiut, Egypt.

\title{
INVESTIGATION OF MILK AND SOME DAIRY PRODUCTS FOR FECAL POLLUTION INDICATORS
} (With 6 Tables)

By

\section{ENAS EL-PRINCE; MOHAMMED SAYED*; MAHMOUD FARGHALY** and AMIRA M. ABDEL-RAHMAN** \\ *Corresponding author (dr.mohammedsayed@yahoo.com)} **Animal Health Research Institute, Assiut Regional Laboratory, Egypt.

(Received at 29/8/2010)

\section{فحص اللبن وبعض منتجات الألبان لمؤشرات التلوث البرازية \\ إيناس البرنس ، محد سبل ، محمود فرغلي ، أمبرة محد عبل الرحمن}

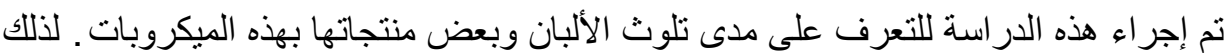

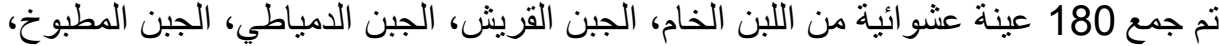

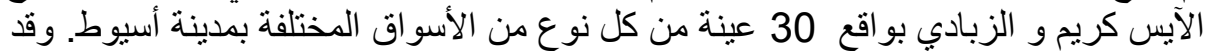

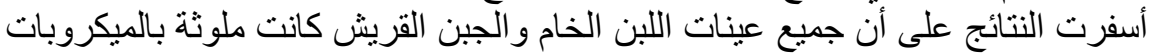

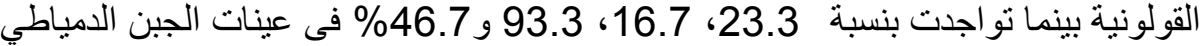

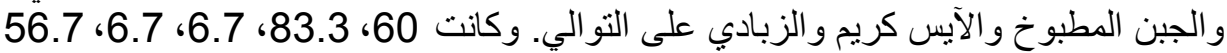

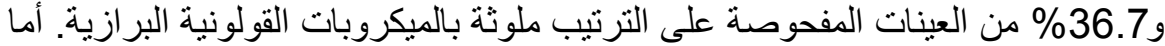

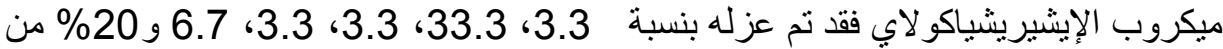

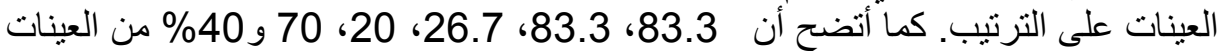

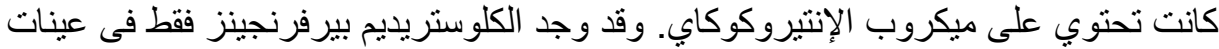

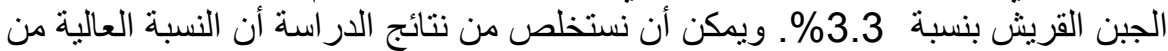
الإنتيروكوكاي تجعلها المفضلة للكثف عنها كمؤشر للتلوث البرازئ البري.

الكلمات الكاثفة: اللبن، منتجات الألبان، مؤشرات التلوث البرازية، الإيشبيريشياكولاي،

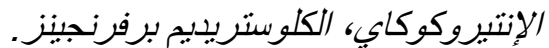

\section{SUMMARY}

The goal of this study was to investigate milk and some dairy products for fecal pollution indicators. Therefore, 180 random samples of raw 
milk, Kareish cheese, Domiati cheese, processed cheese, ice cream and yoghurt (30 each) were collected from Assiut city. All the examined raw milk and Kareish cheese samples were contaminated with coliforms, and their percentages in Domiati cheese, processed cheese, ice cream and yoghurt samples were $23.3,16.7,93.3$ and $46.7 \%$, respectively, while, $60,83.3,6.7,6.7,56.7$ and $36.7 \%$ of the examined samples were contaminated with fecal coliforms, respectively. 3.3, 33.3, 3.3, 3.3, 6.7 and $20 \%$ of the examined samples were contaminated with E. coli, respectively. The incidences of Enterococci were 83.3, 83.3, 26.7, 20, 70 and $40 \%$, respectively, while $\mathrm{Cl}$. perfringens was detected only in Kareish cheese samples in a percentage of $3.3 \%$. It can be concluded that the high level of Enterococci in the examined milk and milk products samples declared that Enterococci is preferable as an indicator for fecal pollution.

Key words: Milk, Milk products, Fecal pollution indicators, E. coli, Enterococci, Cl. perfringens.

\section{INTRODUCTION}

Milk is a food of complex biochemical composition and high water activity serving it as an excellent culture medium for the growth and multiplication of many kinds of microorganisms (Oliver et al., 2005). Among these microorganisms a group of bacteria called enteric pathogens which represent one of the most important bacterial groups in food. Members belonging to this group can survive and multiply in the gastrointestinal tract of humans and animals. Any food contaminated directly or indirectly with fecal material may theoretically contains one or more of these pathogens and thus can be potentially hazardous to consumers. They include Escherichia coli, Enterococci and Clostridium perfringens which are considered the most important fecal indicator pathogens in milk.

In recent years, E. coli has become recognized as a serious foodborne pathogen and has been associated with numerous outbreaks of disease in the UK, Japan and USA (Scotter et al., 2000). E. coli includes a variety of different types that range from avirulent commensally strains that are present in the normal intestinal flora to highly virulent strains that cause a variety of sever infections in both humans and animals. Over 700 antigenic types or serotypes of $E$. coli had been recognized based on $\mathrm{O}, \mathrm{H}$ and $\mathrm{K}$ antigens (Kaper et al., 2004). Their pathogenicity 
is considered to be mainly determined by specific virulence factors such as adhesions, invasions, toxins and capsule.

Raw milk and other dairy products, such as pasteurized milk and yoghurt contaminated with $E$. coli, have been the main cause of several outbreaks of milkborne diseases since the 1980s and thus remain a serious health risk (Seo et al., 1998).

Enterococcus, formally the fecal or Lancefield group D Streptococcus, have been recognized to be of fecal origin since the beginning of this century and the usual ecological niche for Enterococcus species is the intestines of humans and animals. However, they are ubiquitous and can be found free living in soil, on plants, or in dairy products (Leclerc et al., 1996). For many years, Enterococcus species were believed to be harmless to humans and considered unimportant medically because they produce bacteriocins and have been used widely over the last decade in the food industry as starter cultures (Foulquie Moreno et al., 2006). In addition, they are present as active strains in different commercial probiotic preparations as a result of their ability to colonize the gastrointestinal tract and to control pathogenic bacteria (Lund et al., 2002). However, recently Enterococci have been identified as secondary invaders in hospital-acquired infections (Murray, 1998) causing bacteraemia, endocarditis and other infections, with patient having a high mortality rate of up to $61 \%$ (Defátima Silva Lopes et al., 2005). They are able to acquire genetic determinants for antibiotic resistances and among them the resistance to high levels of glycopeptides is of major concern (Bonten et al., 2001). This dual nature of Enterococci gives rise to concern about the safety of using enterococcal probiotics or as starter cultures in the food industry (Lund and Edlund, 2001).

Different Enterococcus species are found in dairy products but Ent. faecalis and Ent. faecium remain the species of greatest importance (Gelsomino et al., 2001). Moreover, Enterococci organisms have a distinctive role as an indicator of poor factory sanitation so that, they were enumerated and isolated from milk and milk products by many workers.

$\mathrm{Cl}$. perfringens is widely distributed in nature occurring in soil, sewage, stool and intestinal tract of animals and humans (Steele and Wright, 2001). It is a classical agent of foodborne disease characterized by mildness and self limiting nature (Snaz et al., 2002). The virulence of the organism is associated with the production of several toxins (exotoxin and enterotoxin). Moreover, the enterotoxigenic strains are a 
common cause of food poisoning outbreaks worldwide (Labbe, 1991). $\mathrm{Cl}$. perfringens enterotoxin (CPE), which is produced during the sporulation phase, causes the symptoms of $\mathrm{Cl}$. perfringens food poisoning (Labbe, 1989). The illness is caused by ingestion of food containing a large number $\left(>10^{5} \mathrm{cfu} / \mathrm{g}\right)$ of vegetative enterotoxigenic $\mathrm{Cl}$. perfringens cells (Shandera et al., 1983). The ingested bacteria multiply and sporulate, releasing CPE into the intestine causing watery diarrhea, abdominal pain, gas and necrotic enteritis in humans (Wise and Sirgusa, 2005).

Cl. perfringens has been isolated from dairy products and its presence could be attributed to contamination of raw milk used in production because its spores being heat resistant, and would not be destroyed during processing (Sinha and Sinha, 1986).

According to the public health hazard of fecal pollution microorganisms, there is a need to investigate milk and some dairy products sold in Assiut city for the incidence of E. coli, Enterococci and $\mathrm{Cl}$. perfringens, so that the best indicator of direct fecal contamination or plant sanitation in milk and some dairy products could be developed.

\section{MATERIALS and METHODS}

\section{Samples:}

A total of 180 random samples of raw milk and some milk products including Kareish cheese, Domiati cheese, processed cheese, ice cream and yoghurt (30 samples each) were collected from various dairy shops, street vendors and supermarkets in Assiut city. All samples were collected in dry, clean and sterile containers and transferred to the laboratory with a minimum of delay. All samples were prepared for bacteriological examination according to APHA (1992).

Bacteriological examination:

I- Coliforms, fecal coliforms and E. coli: Presumptive test for coliforms, confirmed test for coliforms, confirmed test for fecal coliforms and E. coli counts (MPN/ml or g) were carried out according to APHA (1992).

Identification of E. coli isolates: Morphological characteristic and biochemical tests were applied according to APHA (1992).

II- Enterococci:

- Enumeration of Enterococci was described by Deibel and Hartman (1982). 
- Isolation and identification of Enterococci was carried out according to Morrison et al. (1997).

Identification of Enterococci isolates:

- Morphological characteristic: Microscopical examination (APHA, 1992) and motility test (Baron et al., 1994).

- Biochemical tests: Catalase test (Finegold and Martin, 1982), growth at $\mathrm{NaCl}$ 6.5\% (Sherman, 1937), sugar fermentation reaction (APHA, 1984), pyruvate fermentation (Gross et al., 1975).

III- Clostridium perfringens:

Enumeration and identification of $\mathrm{Cl}$. perfringens (MPN/ml or g) was done according to Beerens et al. (1980).

\section{RESULTS}

Table 1. Incidence of fecal pollution indicators in the examined samples (no. $=30)$.

\begin{tabular}{|l|c|c|c|c|c|c|c|c|c|c|}
\hline \multirow{2}{*}{ Products } & \multicolumn{2}{|c|}{ Coliforms } & \multicolumn{2}{c|}{$\begin{array}{c}\text { Fecal } \\
\text { coliforms }\end{array}$} & \multicolumn{2}{c|}{ E. coli } & \multicolumn{2}{c|}{ Enterococci } & \multicolumn{2}{c|}{$\begin{array}{c}\text { Cl. } \\
\text { perfringens }\end{array}$} \\
\cline { 2 - 13 } & $\begin{array}{l}\text { Positive } \\
\text { samples }\end{array}$ & $\%$ & $\begin{array}{l}\text { Positive } \\
\text { samples }\end{array}$ & $\%$ & $\begin{array}{l}\text { Positive } \\
\text { samples }\end{array}$ & $\%$ & $\begin{array}{c}\text { Positive } \\
\text { samples }\end{array}$ & $\%$ & $\begin{array}{c}\text { Positive } \\
\text { samples }\end{array}$ & $\%$ \\
\hline Raw milk & 30 & 100 & 18 & 60 & 1 & 3.3 & 25 & 83.3 & - & - \\
\hline $\begin{array}{l}\text { Kareish } \\
\text { cheese }\end{array}$ & 30 & 100 & 25 & 83.3 & 10 & 33.3 & 25 & 83.3 & 1 & 3.3 \\
\hline $\begin{array}{l}\text { Domiati } \\
\text { cheese }\end{array}$ & 7 & 23.3 & 2 & 6.7 & 1 & 3.3 & 8 & 26.7 & - & - \\
\hline $\begin{array}{l}\text { Processed } \\
\text { cheese }\end{array}$ & 5 & 16.7 & 2 & 6.7 & 1 & 3.3 & 6 & 20 & - & - \\
\hline Ice cream & 28 & 93.3 & 17 & 56.7 & 2 & 6.7 & 21 & 70 & - & - \\
\hline Yoghurt & 14 & 46.7 & 11 & 36.7 & 6 & 20 & 12 & 40 & - & - \\
\hline
\end{tabular}

Table 2. Frequency distribution of the positive samples based on their coliforms count.

\begin{tabular}{|c|c|c|c|c|c|c|c|c|c|c|c|c|}
\hline \multirow{2}{*}{ Range } & \multicolumn{2}{|c|}{$\begin{array}{c}\text { Raw } \\
\text { milk }\end{array}$} & \multicolumn{2}{|c|}{$\begin{array}{c}\text { Kareish } \\
\text { cheese }\end{array}$} & \multicolumn{2}{c|}{$\begin{array}{c}\text { Domiati } \\
\text { cheese }\end{array}$} & \multicolumn{2}{c|}{$\begin{array}{c}\text { Processed } \\
\text { cheese }\end{array}$} & \multicolumn{2}{|c|}{ Ice cream } & \multicolumn{2}{c|}{ Yoghurt } \\
\cline { 2 - 14 }$y$ & No. & $\%$ & No. & $\%$ & No. & $\%$ & No. & $\%$ & No. & $\%$ & No. & $\%$ \\
\hline $3-<10$ & - & - & 1 & 3.3 & 3 & 42.8 & 2 & 40 & 2 & 7.2 & 5 & 35.7 \\
\hline $10-<10^{2}$ & 3 & 10 & 4 & 13.3 & 2 & 28.6 & 1 & 20 & 6 & 21.4 & 3 & 21.4 \\
\hline $10^{2}-<10^{3}$ & - & - & 2 & 6.7 & 1 & 14.3 & 1 & 20 & 6 & 21.4 & 1 & 7.2 \\
\hline $10^{3}-<10^{4}$ & 27 & 90 & 23 & 76.7 & 1 & 14.3 & 1 & 20 & 14 & 50 & 5 & 35.7 \\
\hline
\end{tabular}


Table 3. Frequency distribution of the positive samples based on their fecal coliforms count.

\begin{tabular}{|c|c|c|c|c|c|c|c|c|c|c|c|c|}
\hline \multirow{2}{*}{ Range } & \multicolumn{2}{|c|}{ Raw milk } & \multicolumn{2}{|c|}{$\begin{array}{c}\text { Kareish } \\
\text { cheese }\end{array}$} & \multicolumn{2}{c|}{$\begin{array}{c}\text { Domiati } \\
\text { cheese }\end{array}$} & \multicolumn{2}{c|}{$\begin{array}{c}\text { Processed } \\
\text { cheese }\end{array}$} & \multicolumn{2}{|c|}{ Ice cream } & \multicolumn{2}{|c|}{ Yoghurt } \\
& No. & $\%$ & No. & $\%$ & No. & $\%$ & No. & $\%$ & No. & $\%$ & No. & $\%$ \\
\hline $3-<10$ & - & - & 2 & 8 & - & - & 2 & 100 & 2 & 11.8 & 4 & 36.3 \\
\hline $10-<10^{2}$ & 3 & 16.7 & 2 & 8 & 2 & 100 & - & - & 6 & 35.3 & 1 & 9.1 \\
\hline $10^{2}-<10^{3}$ & 2 & 11.1 & - & - & - & - & - & - & 3 & 17.6 & 1 & 9.1 \\
\hline $10^{3}-<10^{4}$ & 13 & 72.2 & 21 & 84 & - & - & - & - & 6 & 35.3 & 5 & 45.5 \\
\hline
\end{tabular}

Table 4. Frequency distribution of the positive samples based on their $E$. coli count.

\begin{tabular}{|c|c|c|c|c|c|c|c|c|c|c|c|c|}
\hline \multirow{2}{*}{ Range } & \multicolumn{2}{|c|}{ Raw milk } & \multicolumn{2}{|c|}{$\begin{array}{c}\text { Kareish } \\
\text { cheese }\end{array}$} & \multicolumn{2}{c|}{$\begin{array}{c}\text { Domiati } \\
\text { cheese }\end{array}$} & \multicolumn{2}{c|}{$\begin{array}{c}\text { Processed } \\
\text { cheese }\end{array}$} & \multicolumn{2}{|c|}{$\begin{array}{c}\text { Ice } \\
\text { cream }\end{array}$} & \multicolumn{2}{|c|}{ Yoghurt } \\
& No. & $\%$ & No. & $\%$ & No. & $\%$ & No. & $\%$ & No. & $\%$ & No. & $\%$ \\
\hline $3-<10$ & 1 & 100 & 3 & 30 & - & - & 1 & 100 & - & - & 3 & 50 \\
\hline $10-<10^{2}$ & - & - & - & - & 1 & 100 & - & - & 1 & 50 & 1 & 16.7 \\
\hline $10^{2}-<10^{3}$ & - & - & - & - & - & - & - & - & - & - & 1 & 16.7 \\
\hline $10^{3}-<10^{4}$ & - & - & 7 & 70 & - & - & - & - & 1 & 50 & 1 & 16.7 \\
\hline
\end{tabular}

Table 5. Frequency distribution of the positive samples based on their Enterococci count.

\begin{tabular}{|c|c|c|c|c|c|c|c|c|c|c|c|c|}
\hline \multirow[t]{2}{*}{ Range } & \multicolumn{2}{|c|}{$\begin{array}{l}\text { Raw } \\
\text { milk }\end{array}$} & \multicolumn{2}{|c|}{$\begin{array}{l}\text { Kareish } \\
\text { cheese }\end{array}$} & \multicolumn{2}{|c|}{$\begin{array}{l}\text { Domiati } \\
\text { cheese }\end{array}$} & \multicolumn{2}{|c|}{$\begin{array}{l}\text { Processed } \\
\text { cheese }\end{array}$} & \multicolumn{2}{|c|}{ Ice cream } & \multicolumn{2}{|c|}{ Yoghurt } \\
\hline & No. & $\%$ & No. & $\%$ & No. & $\%$ & No. & $\%$ & No. & $\%$ & No. & $\%$ \\
\hline$*<10^{2}$ & 1 & 4 & 2 & 8 & 1 & 12.5 & 4 & 66.6 & 7 & 33.3 & 2 & 16.7 \\
\hline $10^{2}-<10^{3}$ & 5 & 20 & 1 & 4 & 2 & 25 & - & - & 1 & 4.9 & 3 & 25 \\
\hline $10^{3}-<10^{4}$ & 4 & 16 & 1 & 4 & 2 & 25 & 1 & 16.7 & 2 & 9.5 & 4 & 33.3 \\
\hline $10^{4}-<10^{5}$ & 8 & 32 & 2 & 8 & 1 & 12.5 & 1 & 16.7 & 2 & 9.5 & 1 & 8.3 \\
\hline $10^{5}-<10^{6}$ & 6 & 24 & 8 & 32 & 2 & 25 & - & - & 7 & 33.3 & 2 & 16.7 \\
\hline $10^{6}-<10^{7}$ & 1 & 4 & 11 & 44 & - & - & - & - & 2 & 9.5 & - & - \\
\hline
\end{tabular}

* No colonies could be detected on the plates but the organism could be isolated. 
Table 6. Incidence of Enterococci strains recovered from the examined samples.

\begin{tabular}{|l|c|c|c|c|c|c|c|c|c|c|c|c|}
\hline \multirow{2}{*}{ Isolated strains } & \multicolumn{2}{|c|}{ Raw milk } & \multicolumn{2}{|c|}{$\begin{array}{c}\text { Kareish } \\
\text { cheese }\end{array}$} & \multicolumn{2}{c|}{$\begin{array}{c}\text { Domiati } \\
\text { cheese }\end{array}$} & $\begin{array}{c}\text { Processed } \\
\text { cheese }\end{array}$ & \multicolumn{2}{c|}{ Ice cream } & \multicolumn{2}{c|}{ Yoghurt } \\
\cline { 2 - 16 } & No./30 & $\%$ & No./30 & $\%$ & No./30 & $\%$ & No./30 & $\%$ & No./30 & $\%$ & No./30 & $\%$ \\
\hline Ent. faecalis & 13 & 43.3 & 7 & 23.3 & 5 & 16.7 & 1 & 3.3 & 1 & 3.3 & 1 & 3.3 \\
\hline Ent. faecium & 8 & 26.7 & 8 & 26.7 & 1 & 3.3 & 2 & 6.7 & 12 & 40 & 6 & 20 \\
\hline Ent. hirae & - & - & 2 & 6.7 & - & - & 3 & 10 & - & - & 1 & 3.3 \\
\hline Ent. durans & - & - & 3 & 10 & - & - & - & - & 1 & 3.3 & - & - \\
\hline Ent. dispare & 1 & 3.3 & 1 & 3.3 & - & - & - & - & 1 & 3.3 & - & - \\
\hline Ent. mundtii & 3 & 10 & 1 & 3.3 & 2 & 6.7 & - & - & - & - & 4 & 13.3 \\
\hline $\begin{array}{l}\text { Ent. } \\
\text { saccharolyticus }\end{array}$ & - & - & 3 & 10 & - & - & - & - & 3 & 10 & - & - \\
\hline Ent. cecorum & - & - & - & - & - & - & - & - & 2 & 6.7 & - & - \\
\hline Ent. columbae & - & - & - & - & - & - & - & - & 1 & 3.3 & - & - \\
\hline
\end{tabular}

\section{DISCUSSION}

The obtained results summarized in Table 1 showed that coliforms, fecal coliforms, E. coli and Enterococci were detected in all the examined samples of milk and milk products. However, $\mathrm{Cl}$. perfringens was recovered from $3.3 \%$ of the evaluated Kareish cheese samples only, while it failed to be detected in the other products.

The existence of coliforms and fecal coliforms in the examined raw milk samples were in parallel with those recorded by El-Zamkan (2007) and Abd El-Hameid (2002), respectively; while their presence in the examined Kareish cheese samples was in accordance to El-Zamkan (2007) and Ahmed et al. (1987), respectively.

From Table 2 it was clear that the majority of the examined Kareish cheese samples (96.7\%) and ice cream samples (86.7\%) did not comply with Egyptian Standards (2005a; 2005b) which recorded that coliforms must not exceed the level of $10 \mathrm{cfu} / \mathrm{g}$. While, $90 \%$ of the examined processed cheese samples were in order with that standard. For Domiati cheese, 4 samples (13.3\%) were above this standard. Egyptian Standards (2005c) reported that yoghurt must be free from coliforms, thus it was found that $46.7 \%$ of examined samples were not statutory with this standard and of inferior quality.

For fecal coliforms, Table 3 showed to what extent that raw milk, Kareish cheese, ice cream and yoghurt contained high frequencies in comparison with Domiati and processed cheeses.

Egyptian Standards (2005a, b, c and d) recorded that all the concerning samples must be free from E. coli. The obtained data 
presented in Table 4 indicated that, 3.3\% of raw milk, Domiati and processed cheese samples did not comply with these standards, while $33.3 \%$ of Kareish cheese samples also did not comply with it, fortunately, the majority 93.3 and $80 \%$ of ice cream and yoghurt samples respectively comply with its standards.

About Enterococci, It was clearly evident from Table 1 that Enterococci was existed in higher incidences in the concerning samples as compared with the level of $E$. coli or $C l$. perfringens. This observation could be attributed to the greater resistance of Enterococci species to various unfavorable conditions such as salt content of Kareish and Domiati cheeses. As well as, the heat treatment applied during the manufacturing of processed cheese, freezing state of ice cream and low $\mathrm{pH}$ value of yoghurt. Consequently, greater resistance of Enterococci when compared with classical indicators of coliforms under unfavorable condition has led to an increasing tendency to include Enterococci in microbiological criteria as an indication of direct fecal contamination in various food products (Jay, 1992; Knudtson and Hartman, 1993; Audicana et al., 1995).

In addition, there was an extremely low level of $\mathrm{Cl}$. perfringens in contrast to higher rate of $E$. coli as demonstrated in the tested samples. This finding is in good agreement with the result estimated by Abd ElRahman et al. (1994) that E. coli was able to mask the growth of toxigenic types of $\mathrm{Cl}$. perfringens. This is because the ability of $E$. coli to produce colicins which have a role on the inhibition of other bacteria. Production of colicins from E. coli was also stated by other investigators (Djqnne, 1986; Ayhan and Aydin, 1989; Cong et al., 1992).

Table 6 showed the incidence of the isolated Enterococci strains, in which, 9 strains were identified with high incidence in the examined raw milk, Kareish cheese and ice cream samples. Ent. faecalis and Ent. faecium were the most predominant strains. Ent. faecalis was isolated with high incidence $43.3 \%$ from raw milk followed by $23.3 \%$ from Kareish cheese whereas also Ent. faecium isolated with $40 \%$ from the examined ice cream samples.

In conclusion, the high level of Enterococci in the examined milk and milk products samples declared that Enterococci is preferable as fecal pollution indicator, while $E$. coli and $C l$. perfringens should be included in food criteria as indicators of sanitation rather than fecal contamination. This result agreed to some extent with that recorded by Turantas (2002), Bahout and Moustafa (2006) who claimed that the levels of Enterococci were higher than fecal coliforms in ice cream and 
frozen vegetables as well as Kareish cheese and thus favoring Enterococci as better indicators of contamination in such foods. Furthermore, this investigation indicated that the evaluated samples collected from the local markets in Assiut city were of poor sanitary quality which means fecal pollution and could pose a considerable risk to consumers.

\section{REFERENCES}

Abd El-Hameid, Karima G. (2002): Studies on the sanitary conditions of raw milk in Qena Governorate. M.V.Sc. Thesis, Fac. Vet. Med., Assiut Univ., Egypt.

Abd El-Rahman, M.; El-Bardisy, M.M.; Abd-El-Gaber, G. and Ahmed, H.F. (1994): A study on E. coli and Cl. perfringens in buffaloe's milk. Giza. Vet. Med. J. 42(2):119-124.

Ahmed, A.A-H.; Moustafa, M.K. and Abd El-Hakiem, E.H. (1987):

Sanitary condition of Kareish cheese manufactured in Assiut city. Assiut Vet. Med. J., 19(37):76-80.

APHA (American Public Health Association) (1984): Compendium of Methods for the Microbiological Examination of Foods. $2^{\text {nd }}$ Ed., Speck, H.L. (Ed.), Washington D.C., USA.

APHA (American Public Health Association) (1992): Compendium of Methods for the Microbiological Examination of Foods. $16^{\text {th }}$ Ed., Washington D.C., USA.

Audicana, A.; Perales, I. and Borrego, J.J. (1995): Modification of Kanamycin-Esculin-Azid agar to improve selectivity in the enumeration of faecal Streptococci from water samples. Appl. Environ. Microbiol. 61:4178-4183.

Ayhan, H. and Aydin, N. (1989): Studies in the colicinogenic characteristics of $E$. coli strains isolated from man and animals. Etlik Veteriner Mikrobiyoloji Dergisi, 6(4):91-99.

Bahout, A.A. and Moustafa, A.H. (2006): Occurrence of some microorganisms in relation to public health in Kareish cheese. Assiut Vet. Med. J. 52(3):85-92.

Baron, Ellen J.O.; Perteson, L.R. and Finegold, S.M. (1994): Bailey and Scott's Diagnostic Microbiology. $9^{\text {th }}$ Ed., Shanaton, J.F. (Ed.), Mosby-Year Book, Inc.

Beerens, H.; Romond, Ch.; Lepage, C. and Criquelion, J. (1980): A direct method for the enumeration of $\mathrm{Cl}$. perfringens in foods 
and feces. World Congress Foodborne Infections and Intoxications, Berlin (West): 691-695.

Bonten, M.J.; Willems, R. and Weinstein, R.A. (2001): Vancomycinresistant Enterococci: why are they here, and where do they come from? Lancet Infect. Dis. 1:1314-1325.

Cong, T.T.; Milon, A.; Boury, M. and Tasca, C. (1992): Colicins and resistance to colonization of E. coli 0103 enterocolitis of weaned rabbits. Revue de Medecine Veterinaire, 143(8/9):655665.

Defátima Silva Lopes, M.; Ribeiro, T.; Abrantes, M.; Figueiredo Marques, J.J.; Tenreiro, R. and Crespo, M.T.B. (2005): Antimicrobial resistance profiles of dairy and clinical isolates and type strains of Enterococci. Int. J. Food Microbiol. 103:191-198.

Deibel, R.H. and Hartman, P.A. (1982): The Enterococci. In: Compendium of Methods for the Microbiological Examination of Foods. Speck, M.L. (Ed.), $2^{\text {nd }}$ Ed., APHA. Inc.

Djqnne, B.K., (1986): Colicin resistance in relation pathogenicity factors in strains of $E$. coli isolated from the intestinal tract of piglets. Acta Vet. Scand. 27(1):115-123.

Egyptian Standards (2005a): Milk and Dairy products. Soft cheese. Egyptian Organization for Standardization and Quality Control. ES: 1008.

Egyptian Standards (2005b): Milk and Dairy Products. Ice cream. Egyptian Organization for Standardization and Quality Control. ES: 1185.

Egyptian Standards (2005c): Milk and Dairy Products. Yoghurt. Egyptian Organization for Standardization and Quality Control. ES: 1633.

Egyptian Standards (2005d): Milk and Dairy products. Processed cheese. Egyptian Organization for Standardization and Quality Control. ES: 999.

El-Zamkan, Mona A. (2007): Coliform bacteria in milk and some dairy products in Qena. M.V.Sc. Thesis, Fac. Vet. Med., South Valley Univ., Egypt.

Finegold, S.M. and Martin, W.J. (1982): Bailley and Scott's Diagnostic Microbiology. $6^{\text {th }}$ Ed., C.V. Mobsy Co., St. Louis, Toronto, London. UK. 
Foulquie Moreno, M.R.; Sarantinopoulous, P.; Tsakalidou, E. and De

Vuyst, L. (2006): The role and application of Enterococci in food and health. Int. J. Food Microbiol. 106:1-24.

Gelsomino, R.; Vancanneyt, M.; ConDon, S.; Swing, J. and CoGan, T.M. (2001): Enterococci diversity in the cheese-making environment of an Irish cheddar type cheese-making factory. Int. J. Food Microbiol. 71:177-188.

Gross, K.C.; Houghton, M.P. and Senterfit, L.B. (1975): Presumptive speciation of Strep. bovis and other group D Streptococci from human sources by using arginine and pyruvate tests. J. Clin. Microbiol. 1:54-60.

ICMSF (International Committee on Microbiological Specification for Foods) (1978): Microorganisms in Foods. I: Their significance and methods of enumeration. $2^{\text {nd }}$ Ed., Univ. of Toronto, Press, Toronto Buffalo London.

Jay, J.M. (1992): Modern Food Microbiology, $4^{\text {th }}$ Ed., pp.: 421-426. New York: AVI Books.

Kaper, J.B.; Nataro, J.P. and Mobely, H.L.T. (2004): Pathogenic E. coli. Nat. Rev. Microbiol. 2:123-140.

Knudtson, L.M. and Hartman, P.A. (1993): Comparison of fluorescent gentamisin-thallous-carbonate and KF Streptococcal agars to enumerate Enterococci and faecal Streptococci in meats. Appl. Environ. Microbiol. 59: 936-941.

Labbe, R.G. (1989): Cl. perfringens. In: Foodborne Bacterial Pathogens. M.P. Doyle (Ed.), Marcel Dekker, pp.: 191-234, New York, N.Y.

Labbe, R.G. (1991): Cl. perfringens. J. Assoc. Off. Anal. Chem. 74:711714.

Leclerc, H.; Devriese, L.A. and Mossel, D.A. (1996): Taxonomical changes in intestinal (faecal) Enterococci and Streptococci consequences on their use as indicators of faecal contamination in drinking water. J. Appl. Bacteriol. 81:459-466.

Lund, B. and Edlund, C. (2001): Probiotic Ent. faecium strain is a possible recipient for the vanA gene cluster. Clin. Infect. Dis. 32:1384-1385.

Lund, B.; Adamsson, I. and Edlund, C. (2002): Gastrointestinal transit survival of an Ent. faecium probiotic strain administered with or without vancomycin. Int. J. Food Microbiol. 77:109-115. 
Morrison, D.; Woodford, N. and Cookson, B. (1997): Enterococci as emerging pathogens of humans. J. Appl. Microbiol., Symposium Supp. 83:89s-99s.

Murray, B.E. (1998): Diversity among multidrug-resistant Enterococci. Emerg. Infect. Dis. 4:37-47.

Oliver, S.P.; Jayarao, B.M. and Almeida, R.A. (2005): Foodborne pathogens in milk and the dairy farm environment: Food safety and public health implications. Foodborne Pathogens and Disease, 2 (2):115-129.

Scotter, S.; Aldridge, M. and Capps, K. (2000): Validation of a method for the detection of E. coli O157: H7 in foods. Food Control, 11:85-95.

Seo, K.H.; Brackett, R.E. and Frank, J.F. (1998): Rapid detection of E. coli O157:H7 using immuno-magnetic flow cytometry in ground beef, apple juice and milk. Int. J. Food Microbiol. 44:115-123.

Shandera, W.X.; Tacket, C.O. and Blake, P.A. (1983): Food poisoning due to $\mathrm{Cl}$. perfringens in the United States. J. Infect. Dis. 147:167-170.

Sherman, J.M. (1937): The Streptococci. Bacteriol. Rev. 1:1-97 (Cited in ICMSF, 1978).

Sinha, R.N. and Sinha, P.R. (1986): Incidence of Clostridia with reference to dairy processing. J. Food Sci. Technol. India, 25 (2):101-102.

Snaz, J.C.; Dominguez, M.F.; Sagues, M.J.; Fernandez, M.; Feito, R.; Noguerales, R.; Asenio, A. and Fernandez Delahoz, K. (2002): Diagnosis and epidemiological investigation of an outbreak of Cl. perfringens food poisoning. Enferm. Inf. Microbiol. Clin. 20 (3):117-122.

Steele, F.M. and Wright, K.H. (2001): Cooling rate effect on outgrowth of $\mathrm{Cl}$. perfringens in cooked, ready-to-eat Turkey breast roasts. Poult. Sci. 6:813-816.

Turantas, F. (2002): Incidence of faecal Streptococci as an indicator of sanitation in ice cream and frozen vegetables. Int. J. Food Sci. Technol. 37(3): 239-243.

Wise, M.G. and Sirgusa, G.R. (2005): Quantitative detection of Cl. perfringens in the broiler foil gastrointestinal tract by real time PCR. Appl. Environ. Microbiol. 71:3911-3961. 